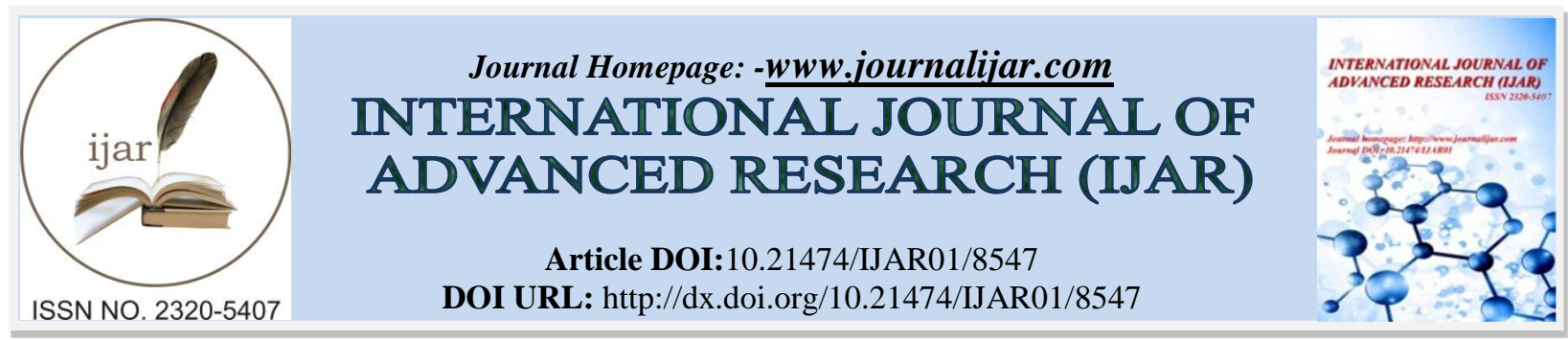

RESEARCH ARTICLE

\title{
EFFETS OF TWO PLANTS PROPAGATION METHODS ON JATROPHA CURCAS (L.) GROWTH AND SEEDS YIELD IN TANDJILE REGION (CHAD).
}

\author{
Kabe Hinlibe Karka ${ }^{1,2}$, Megueni Clautilde ${ }^{1}$, Tchobsala ${ }^{1,3}$ and Tchuenteu Tatchum Lucien ${ }^{1}$. \\ 1. Department of Biological Sciences, Faculty of Sciences, University of Ngaoundéré-Cameroon. \\ 2. Department of Agricultural Sciences, INSATA/ Laï-Tchad. \\ 3. Department of Biological Sciences, Faculty of Sciences, University of Maroua-Cameroon.
}

\section{Manuscript Info}

Manuscript History

Received: 11 December 2018

Final Accepted: 13 January 2019

Published: February 2019

Key words:-

Jatropha curcas; plants propagation methods; seeds yield; Tandjilé (Chad).

\begin{abstract}
Field trial was carried out in Chad to investigate the effects of two plants propagation methods on productivity of Jatropha curcas L. cultivated in four localities (Djoun, Insatal, Laï-Djoum and Tchoua) at Tandjilé region in Chad. Planting was done following a randomized block design with four replications and two treatments (plants propagation methods: cuttings of stem and seedling). Physico-chemical properties of growing soils were assessed. The growing parameters and seeds yield were evaluated. Results shown that growing parameters and seeds yield were significantly different $(p<0.05)$ between both plants propagation methods and four study localities. J. curcas adapted better in Tchoua locality than other three experimental sites. Cuttings of stem exhibited the highest $(104 \pm 1.9 \mathrm{Kg} / \mathrm{ha})$ seeds yield while the lowest $(88 \pm 3.7 \mathrm{Kg} / \mathrm{ha})$ is observed under seedling plants propagation method in each of four study sites. It comes out from this study that plants propagation method using cuttings of stem can be recommended to farmers of Tandjilé region (Chad) to be integrated into their agricultural systems for J. curcas growth.
\end{abstract}

Copy Right, IJAR, 2019,. All rights reserved.

\section{Introduction:-}

National communities, non-governmental organizations, national and international institutions have in recent years become aware the danger posed by the emission of greenhouse gases, particularly carbon dioxide whose fossil fuel constitutes the main emission source (Minengu et al., 2014). Faced with the industries development and exponential growth of world's population, it is urgent to find a source of alternative energy to avoid energy crisis (Fall, 2007; Sall, 2007). Research focuses on bioenergy, particularly on non-edible plants that can produce oils with biofuel potentiality (Dieye, 2007; Bellefontaine, 2001; Nwaga, 2009). Jatropha curcas L., a shrub belonging to the Euphorbiaceae family, is one of the vegetable species that can solve energy problems because the oil extracted from its seeds can be used as biofuels without competing with food crops. J. Curcas growth well in intercropping with food crop (Dauriat et al., 2001, FAO, 2010). This plant is not edible for humans or livestock. It is widely used in traditional medicine. Seeds oil from J. curcas is used in the manufacture of biofuel, handmade soap, ointment and then used as insecticides and nematocides for crops protection (Hammaoui, 2006). The cake obtained after seeds oil extraction is an excellent organic fertilizer for crops (Penjit, 2012). This cake can be used as fodder for livestock after detoxification (Kasuya et al., 2013). The stem of J. curcas is used for hedgerows construction. J. curcas adapts

Corresponding Author:-Kabe Hinlibe Karka.

Address:-Department of Biological Sciences, Faculty of Sciences, University of Ngaoundéré-

Cameroon. 
to various soils, withstands long periods of drought and requires very little maintenance. But its optimal production requires a well-drained and fertile soil (Bellefontaine, 2001; Olivier, 2007). Many countries in the world, including America, Asia and recently some West African countries have embarked on its culture for biofuels production. The Sudanian zone of Chad offers a favorable climate for planting this shrub in order to solve the socio-economic needs of population stricken by poverty. The purpose of this work was to evaluate (1) the physico-chemical characteristics of soils from Sudanian savannah of Tandjilé (Chad), (2) plants propagation methods (seedling and cuttings of stem) as well as localities of Sudanian savannah of Tandjilé (Chad) on J. curcas growth and development. The importance and usefulness of this work follows from the fact that the plants propagation method and the Chad study area which will provide the highest seeds yield of $\mathrm{J}$. curcas will be popularized.

\section{Materials and Methods:-}

\section{Description of experimental sites:-}

The field study took place from May to December 2016 in Tandjilé region, located in southern Chad. Study took place in four localities of this region: Djoun: $09^{\circ} 46^{\prime}$ 03, 4' 'North latitude, $017^{\circ} 10^{\prime} 57,8^{\prime \prime}$ 'East longitude and 382,2 m altitude ; Insatal : $09^{\circ} 17^{\prime} 16,7^{\prime}$ ' North latitude, $016^{\circ} 55^{\prime}$ 47,6' 'East longitude and 334,9m altitude ; Laï-Djom : 09 45'15' $6^{\prime}$ ' North latitude, 018 25'25,7' 'East longitude and 375,4 m altitude and Tchoua : 09 $18^{\circ}$ ' 16,7' 'North latitude, $016^{\circ} 55^{\prime} 47,6^{\prime}$ 'East longitude and 354,9 $\mathrm{m}$ altitude. The climate belongs to Sudanian type, characterized by two seasons: a rainy season (May to October) and a dry season (November to April). Rainfall varies between 800 to $1200 \mathrm{~mm}$. The temperatures present absolute minimums in December-January $\left(15^{\circ} \mathrm{C}\right)$ and averages of the relatively high maxima in March-April $\left(35^{\circ} \mathrm{C}\right.$ ). Annual average temperatures range between $28^{\circ} \mathrm{C}$ and $32^{\circ} \mathrm{C}$ and the relative humidity of the air is maximum (80\%) in July-August-September. The soils are variable depending places (vertisols, tropical ferruginous soils and hydromorphic) and favorable to agriculture and livestock (Anonymous, 2017). The Tandjilé region is located in the Logone basin area. Soil was covered by graminaceous and it is rich in legumes during the rainy season. The dominant tree and shrub species were Combretaceae (Combretum colinum, Combretum aculeatum), Moraceae (Ficus spp), Cesalpinaceae (Piliostigma thonningii), Annonaceae (Annona senegalensis). Also, Sapotaceae (Vitellaria paradoxa) and Mimosaceae (Parkia biglobosa) were observed in our experimental sites.

\section{Materials:-}

Seeds and cuttings of stem of Jatropha curcas are used. They were collected locally. Fruits and cuttings were picked in november 2015 on J. curcas planted in hedge. These plants are 5 years old. Subsequently, the seeds are extracted from the fruits and they were stored in a dry place (room temperature) until the sowing day. These seeds were black in color and presented $1.86 \mathrm{~cm}$ length, $1.10 \mathrm{~cm}$ maximal diameter and $0.72 \mathrm{~g}$ weight at planting. Cuttings presented $2.5 \mathrm{~cm}$ diameter and $60 \mathrm{~cm}$ long and they were made at sowing day..

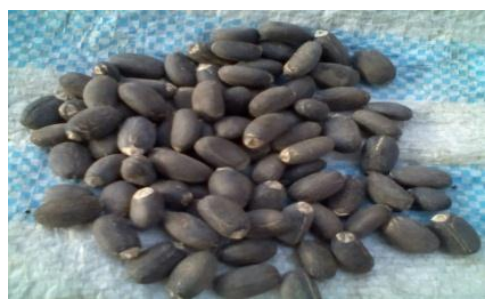

Figure 1:-Seeds of Jatropha curcas

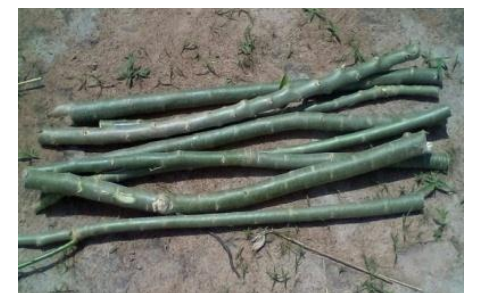

Figure 2:-Cutting of Jatropha curcas 


\section{Methods:-}

Assesment of plants propagation methods on Jatropha curcas growth and yield Land preparation and experimental design:-

All wild plants were cut off from the experimental sites. Thereafter each site was plowed to $50 \mathrm{~cm}$ depth and ridges of $10 \mathrm{~m} \times 6 \mathrm{~m}\left(60 \mathrm{~m}^{2}\right)$ were formed. Space between two consecutive ridges was $3 \mathrm{~m}$. The experimental design consisted of two treatments (plants propagation methods) lay out randomly and repeated in four blocks. The same experimental design was adopted in the four study localities (Djoun, Tchoua, Laï-Djom and Insatal).

\section{Studied parameters and statistical analyzes:-}

Growth parameters (plants height, number of leaves per plant, number of ramification per plant and dry biomass of plants) and production parameters (number of fruits per plant and seeds yield) were assessed on 30 targeted plants. Carbon stock was assesment according to (GIEC, 2006 ; Mugnier et al., 2009) using this formula : CS=BS $\times 0,475$ where $\mathrm{CS}=$ carbon stock and $\mathrm{BS}=$ total biomass of $\mathrm{J}$. curcas plants.

All data were statistically analyzed using the Stagraphic plus Program version 5.0. The significance of differences was determined using Duncan test.

\section{Results and Discussion:-}

\section{Chemical properties of growing soils:-}

Growing soil presents a sand-clay texture with silt levels ranging from $1.68 \%$ to $5.05 \%$. All soil samples have a neutral $\mathrm{pH}$ (6.59-7.38) (table 1), thus suggesting the optimal availability of mineral elements at different experimental sites (Kanabo and Gilkes, 1987). Organic matter and soil carbon content are relatively low (less than $1 \%$ ) (Table 1). Crops have difficulty in extracting nutrients from soil and microfauna activity is reduced when soil organic matter is less than 1\% (Martin et al.. 1990). In this respect, fertilization using compost would increase the agricultural values of our growing soil, but this needs to be investigated. Phosphorus and potassium contents of growing soil range from 250 to $480 \mathrm{ppm}$ and from $100 \mathrm{ppm}$ to $180 \mathrm{ppm}$ respectively. Concerning chemical properties of growing soil. soil from four study sites presented globally a good agricultural values; they are all likely to guarantee a good productivity of plants like Jatropha curcas L. However it would be appropriate to improve the low organic matter content of these soils by adding organic manure.

Table 1:-Physico-chemical properties of growing soils

\begin{tabular}{|l|l|l|l|l|l|l|l|l|l|l|l|l|l|}
\hline \multirow{2}{*}{$\begin{array}{l}\text { Sites of } \\
\text { Study }\end{array}$} & \multicolumn{3}{|c|}{ Texture } & $\mathbf{p H}$ & $\begin{array}{l}\text { Cond } \\
(\boldsymbol{\mu s} / \mathbf{c m})\end{array}$ & $\begin{array}{l}\mathbf{O M} \\
(\boldsymbol{\%})\end{array}$ & $\begin{array}{l}\mathbf{C a} \\
(\boldsymbol{\%})\end{array}$ & $\begin{array}{l}\mathbf{N} \\
(\mathbf{p p m})\end{array}$ & $\begin{array}{l}\mathbf{P} \\
(\mathbf{p p m})\end{array}$ & $\begin{array}{l}\mathbf{K} \\
(\mathbf{p p m})\end{array}$ & $\begin{array}{l}\mathbf{M g} \\
(\mathbf{p p m})\end{array}$ & $\begin{array}{l}\mathbf{C a} \\
(\mathbf{p p m})\end{array}$ & $\begin{array}{l}\mathbf{F e} \\
(\mathbf{m g} / \mathbf{g})\end{array}$ \\
\hline Djoun & 86.68 & 3.14 & 10.18 & 6.97 & 22.19 & 0.03 & 0.01 & 10.18 & 250 & 145.0 & 20.00 & 245.0 & 8.00 \\
\hline Insatal & 88.19 & 2.02 & 9.79 & 6.64 & 20.46 & 0.05 & 0.03 & 35.75 & 255 & 157.5 & 47.00 & 260.0 & 6.05 \\
\hline Laï-Djom & 89.19 & 1.68 & 9.13 & 6.70 & 18.9 & 0.04 & 0.03 & 5.50 & 260 & 140.0 & 37.50 & 250.0 & 11.00 \\
\hline Tchoua & 87.17 & 2.37 & 10.46 & 6.59 & 53.7 & 0.06 & 0.04 & 66.00 & 265 & 175.0 & 55.00 & 250.0 & 1.10 \\
\hline Mean & 87.80 & 2.30 & 9.89 & 6.72 & 24.08 & 0.05 & 0.03 & 29.35 & 257 & 154.4 & 39.87 & 251.2 & 6.53 \\
\hline
\end{tabular}

Cond: C onductivity, OM: Organic matter

Effect of plants propagation methods on Jatropha curcas growth and development Plants height, number of leaves per plant and number of bunches per plant:-

The analysis of variance (ANOVA) shows that there is no significant difference on plant height between both plants propagation methods (seedling and cuttings of stem). However the four experimental sites influence significantly $(\mathrm{p}<0,05)$ the height of Jatropha curcas plants (table 2). Plants from Tchoua locality exhibited the highest $(62.89 \pm$ $1.30 \mathrm{~cm}$ ) plant height.

Furthermore, both plants propagation methods and the four experimental sites influence significantly $(\mathrm{p}<0,05)$ foliar production and number of bunches per plant. The greatest $(70.60 \pm 2.56)$ number of leaves per plant is observed on J. curcas plants growth in Tchoua locality while Djoum experimental site exhibited the lowest (49.93 \pm 1.19$)$ value of this growth parameter. 
Table 2:-Plants height, number of leaves per plant and number of bunches per plant depending experimental site

\begin{tabular}{|l|l|l|l|l|l|l|}
\hline \multirow{3}{*}{$\begin{array}{c}\text { Experimental } \\
\text { sites }\end{array}$} & \multicolumn{5}{|c|}{ Plants propagation methods } \\
\cline { 2 - 7 } & \multicolumn{1}{|c|}{ Seedling } & \multicolumn{1}{c|}{ Cuttings of stem } \\
\cline { 2 - 7 } & \multicolumn{1}{|c|}{ PH (cm) } & \multicolumn{1}{|c|}{ NLP } & \multicolumn{1}{c|}{ PH $(\mathbf{c m})$} & \multicolumn{1}{c|}{ NLP } & NBP \\
\hline Djoun & $44.23 \pm 0.47^{\mathrm{a}}$ & $50.06 \pm 0.94^{\mathrm{a}}$ & $4.46 \pm 1.08^{\mathrm{a}}$ & $40.63 \pm 0.47^{\mathrm{a}}$ & $49.80 \pm 1.43^{\mathrm{a}}$ & $9.96 \pm 0.72^{\mathrm{a}}$ \\
\hline Insatal & $56.56 \pm 0.97^{\mathrm{c}}$ & $63.8 \pm 1.07^{\mathrm{b}}$ & $4.51 \pm 1.17^{\mathrm{a}}$ & $47.5 \pm 1.06^{\mathrm{b}}$ & $73.53 \pm 3.23^{\mathrm{b}}$ & $9.96 \pm 0.12^{\mathrm{a}}$ \\
\hline Laï-Djoum & $50.46 \pm 1.33^{\mathrm{b}}$ & $54.66 \pm 0.70^{\mathrm{a}}$ & $8.06 \pm 1.94^{\mathrm{b}}$ & $47.70 \pm 0.8^{\mathrm{b}}$ & $87.00 \pm 2.53^{\mathrm{c}}$ & $11.00 \pm 0.24^{\mathrm{a}}$ \\
\hline Tchoua & $61.73 \pm 1.24^{\mathrm{c}}$ & $70 \pm 2.9^{\mathrm{b}}$ & $12.00 \pm 0.46^{\mathrm{c}}$ & $64.06 \pm 1.37^{\mathrm{c}}$ & $87.20 \pm 2.26^{\mathrm{c}}$ & $15.40 \pm 0.59^{\mathrm{b}}$ \\
\hline
\end{tabular}

PH : Plants height; NLP : Number of leaves per plant ; NBP : Number of bunches per plant.

Values in the same column for each plants propagation method followed by the same letter are not significantly different.

Plant leaves absorb $\mathrm{co}_{2}$ through photosynthesis, thus contributing to fight against climate change. It can also limit sunstroke, increase soil moisture content and reduce erosion (Ouédraogo, 2000; Singh and Rathod, 2002; Tchuenteu et al., 2013). Plants leaves represent a biomass that can be degraded and released nutrient necessary for improving soil fertility and plants nutrition (Bunch, 2004; Sall, 2007). In the present study, Tchoua locality exhibited the greatest foliar production, suggesting that J. curcas' cultivation in Tchoua locality would contribute effectively to fight against climate change as well as improving soil fertility compared to other three experimental sites, but this remains to be studied. In this study, plants height, foliar production and number of bunches per plant vary according to experimental area, this result does not surprise us: indeed, several authors (Reinhard and Tianasoa, 2005; Fresco, 2003 and Megueni et al., 2011) reported that plants growth parameters vary depending cultural practice and experimental area.

\section{Dry biomass and carbon stock:-}

The dry biomass, carbon stock and equivalent $\mathrm{CO}_{2}$ sequestred depending experimental site and plants propagation method are presented in table 2. The analysis of variance (ANOVA) showed that both plants propagation methods and the four study localities influenced significantly $(\mathrm{P}<0.001)$ the dry biomass of plants of J. curcas, consequently carbon stock and equivalent $\mathrm{CO} 2$ sequestered. Plants with a high biomass correspond to those with high carbon values sequestered by photosynthesis mechanism (Tchobsala, 2016). Plants from Tchoua locality exhibited the highest $(0.26 \pm 0.03 \mathrm{Kg})$ dry biomass, consequently the highest $(0.13 \pm 0.05 \mathrm{Kg})$ carbon stock compared to those from other localities. In this respect, the culture of J. curcas in Tchoua locality would contribute effectively to fight against climate change compared to Djoun, Insatal and Laï-Djoum areas.

Table 3: Dry biomass and carbon stock depending plants propagation method and experimental area

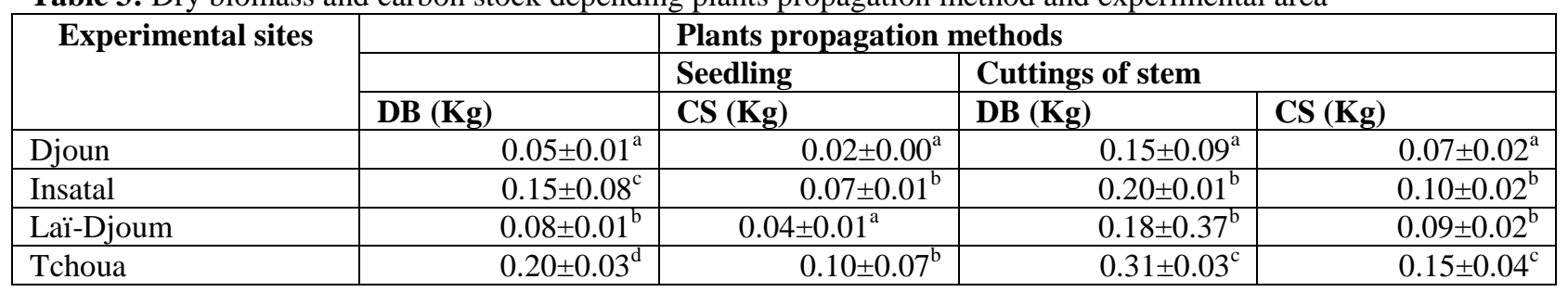

DB : dry biomass ; CS : Carbon stock, ECS ; Values in the same column for each seedling mode followed by the same letter are not significantly different.

\section{Number of fruits per plant and seeds yield of Jatropha curcas plants:-}

Both plants propagation methods as well as different study areas significantly $(\mathrm{P}<0.001)$ influence the number of fruits per plant and seeds yield of J. curcas. Seeds yield vary from $55 \pm 4.92 \mathrm{Kg} / \mathrm{ha}$ in Djoum locality to $104 \pm 1.90$ $\mathrm{Kg} / \mathrm{ha}$ to Tchoua locality. Globally Tchoua locality exhibited the highest $(96 \pm 2.82 \mathrm{Kg} / \mathrm{ha})$ seeds yield while the lowest $(57.5 \pm 3.22 \mathrm{Kg} / \mathrm{ha})$ is observed in Djoun locality. The seeds yield from cuttings plants propagation methods is higher $(72 \pm 3.15 \mathrm{Kg} / \mathrm{ha})$ than that from seedling plants propagation method $(66 \pm 3.9 \mathrm{Kg} / \mathrm{ha})$.

In this study growing and production parameters of J. curcas vary according to study area. This result corroborates data found in literature. Indeed, several authors (Koutroubass et al. 1999; Tchuenteu et al., 2013 and Derogoh et al., 2018) reported that plant productivity vary depending experimental area. In this study, seeds yield ranged from $55 \pm$ $4.92 \mathrm{Kg} / \mathrm{ha}$ to $104 \pm 1.90 \mathrm{Kg} / \mathrm{ha}$. These values are lower than data found in littérature. The low seed yield obtained in this study is due to the fact that no fertilizer was applied in this work. Seeds yield can be improved if soil 
amendment, cultural and growing conditions are improved. Indeed, Bambang et al. (2016) study the yield performance of J. curcas after pruning during five years production cycles in North Lombok dry land, Indonesia and reported that The total yield was higher (16.314.6 kg Ha-1), compared to un-pruned tree (14.800.1 kg Ha-1). In addition,

Chengxin et al. (2014) study on a new J. curcas variety (JO S2) with improved seed productivity and found that this J. curcas variety produced up to 2.95 ton/ha of dry seeds in the first year and up to 4.25 ton/ha of dry seeds in the second year, much better than the local variety control. the small seed yield obtained in this study can be explained by the fact that this work was not carried out under the same experimental conditions as those of our predecessors. In addition, it was been reported that plant productivity vary according to genotype, experimental area, and year of experimentation (Koutroubass et al., 1999, Tchuenteu et al., 2013). In this study, Tchoua locality is more favorable for J. curcas growth compared to Djoun, Insalta and Lai-Djoum. Moreover, J. curcas growth and seeds yield is higher under cuttings of stem plants propagation medthod than under seeds propagation.

Table 4:-Number of fruits per plant and seeds yield of Jatropha curcas

\begin{tabular}{|c|c|c|c|c|}
\hline \multirow[t]{3}{*}{ Localities } & \multicolumn{4}{|c|}{ Plants propagation methods } \\
\hline & \multicolumn{2}{|c|}{ Seedling } & \multicolumn{2}{|c|}{ Cuttings of stem } \\
\hline & NFP & SY (kg/ha) & NFP & SY (kg/ha) \\
\hline Djoun & $31 \pm 1.63^{\mathrm{a}}$ & $60 \pm 1.52^{a}$ & $29 \pm 1.52^{\mathrm{a}}$ & $55 \pm 4.92^{\mathrm{a}}$ \\
\hline Insatal & $30 \pm 2.70^{\mathrm{a}}$ & $57 \pm 6.53^{a}$ & $39 \pm 2.52^{\mathrm{a}}$ & $74 \pm 3.51^{b}$ \\
\hline Laï-Djoum & $31 \pm 1.77^{\mathrm{a}}$ & $59 \pm 3.81^{\mathrm{a}}$ & $30 \pm 3.57^{\mathrm{a}}$ & $56 \pm 2.3^{\mathrm{a}}$ \\
\hline Tchoua & $46 \pm 3.30^{b}$ & $88 \pm 3.74^{b}$ & $55 \pm 3.57^{b}$ & $104 \pm 1.90^{c}$ \\
\hline
\end{tabular}

NFP : Number of fruits per plant ; SY : Seeds yield

Values in the same column for each seedling mode followed by the same letter are not significantly different.

\section{Conclusion:-}

Soils from Sudanian savannah zone of Chad are favorable for well Jatropha curcas growing. The growing parameters of J. curcas as well as seeds yield vary depending study area and plants propagation method. J. curcas plants from Tchoua locality exhibited the highest growing parameters and seeds yield (96 $\pm 2.82 \mathrm{Kg} / \mathrm{ha})$. Cuttings of stem exhibited the highest $(104 \pm 1.9 \mathrm{Kg} / \mathrm{ha})$ seeds yield while the lowest $(88 \pm 3.7)$ is observed under seedling plants propagation method in each of four experimental areas. Cuttings of stem propagation method is recommended for J. curcas growing in Chad. Further research will then investigated the effect of organic manure on J. curcas growing in Tchad.

\section{References Bibligraphiques:-}

1. Bambang B S, IGM Arya SP, Bambang SP. 2016. yield performance of Jatropha curcas L. after pruning during five years production cycles in North Lombok dry land, Indonesia. Global Advanced Research Journal of Agricultural Science. 5(3).

2. Bellefontaine R, Petit S, Pain OM, Deleporte P, Bertault JG. 2001. Les arbres hors forêt vers une meilleure prise en compte. F.A.O. Conservation. Rome. 231p.

3. Bunch R 2004. Engrais verts et culture de couverture. Agridape. 19 (1): 16-148.

4. Chengxin Y, Chalapathy RV, Kins HB, Thi Ngoc Z, Shilu K, Manju K, Binoy R, Yan H. 2014. study on a new Jatropha curcas variety (JO S2) with improved seed productivity. Sustainability. 6, 4355-4368; doi:10.3390/su6074355.

5. Dauriat A, Fromentin A, Sarlos G. 2001. Rapport sur les possibilités d'utilisation des Biocarburants à l'Aéroport International de Genève. Ecole polytechnique fédérale de Lausanne. Genève. 129p.

6. Dieye PN. 2007. Les biocarburants : une nouvelle donne pour les politiques agricoles. Agrovision. 4: 14-15.

7. Fall A. 2007. De nouvelles pistes vers la souveraineté énergétique. Agrovision. (4): 10-13.

8. FAO (Organisation des Nations Unies pour l'alimentation et l'agriculture). 2010. Jatropha : A smallholder bioenergy crop the potential for pro-poor development. Integrated crop management. $\mathrm{N}^{\circ}$ 8. FAO.Rome. Italie. $114 \mathrm{pp}$.

9. Fresco OL. 2003. Les engrais et l'avenir. In: la sécurité mondiale et rôle de la fertilisation durable. Maisonneuve Larousse (éds). Conférence IFA/FAO. Rome. Italie.26-28 mars 2003. pp 51-67.

10. GIEC. 2006. Guide pour l'inventaire national des gaz a effet de serre, agriculture, foresterie et autre usage des terres. Institute for Global Environnemental Stratégies. Japon. v4. pp. 4.46 - 4.52. 
11. Hammaoui H. 2006. L'effet nématocide de quelles que plantes sur les nématodes à galles de la culture de tomate. Mémoire de Master. Université d'Agadir. Maroc. 61p.

12. Kanabo IAK, Gilkes RJ. 1987. The role of soil pH in the dissolution of phosphate rock fertilizers. Fert. Res.. 12: $165-174$

13. Kasuya MCM, Da Luz JMR, Pereira LPD, Da Silva JS, Montavani HC, Rodrigues MT. 2013. Biodetoxification of Jatropha seed cake and its use in animal feed. In Biodiesel - Feedstocks. Production and Applications. Zhen Fang (editor). In Tech. Chapters published ; 309-330. DOI : 10.5772/45895

14. Koutroubas SD, Papakosta DK, Doitsinis A. 1999. Adaptation and yielding ability of castor plant (Ricinus communis L.) genotypes in a Meditarranean climate European Journal of Agronomy 11, 227-237.

15. Martin A, Mariotti A, Balesdent J, Lavelle, Voattoux R. 1990. Estimate of organic matter turnover rate in a savannah soil by $13 \mathrm{C}$ natural abundance measurements. Soil Biol. Biochem.. 22: 517-523

16. Megueni C, Awano ET, Ndjouenkeu R. 2011. Effet simultané de la dilution et de la combinaison du Rhizobium et des mycorhizes sur la production foliaire et les propriétés physico-chimiques de jeunes feuilles de Vigna unguiculata (L.) Walp. Journal of Applied Bioscience 40 :2668-2676.

17. Minengu JD, Mobambo P, Mergeai G. 2014. Influence de l'environnement et des pratiques culturales sur la productivité de Jatropha curcas L. en Afrique subsaharienne (synthèse bibliographique). 18 (2) : 290-300.

18. Mugnier A, Cassagne B, Bayo N, Lafon C. 2009. Estimation des stocks de carbone des forets du Bassin du Congo pour le REDD : étude comparative conduite sur 22 types forestiers. 4 pays et un dispositif d'aménagement 4.8 millions d'ha. XIII World Forestry Congress. Buenos Aires. Argentina. 18 - 23 October 2009.

19. Nwaga D. 2009. Biocarburants. sols marginaux et sécurité alimentaire. 25p. In Biosciences and Food Security. $16^{\text {ème }}$ Conférence du Comité Camerounais des Biosciences. 105p.

20. Olivier D. 2007. Jatropha curcas: une plante à très fort potentiel: In planète bleue. Poésie en image et Ecologie en action. Actualité de l'environnement. $7 \mathrm{p}$.

21. Ouédraogo M. 2000. Etude biologique et physiologie du Phourgère. Jatrpha curcas L. thèse d'Etat. Université de Ouagadougou. Burkina-Faso. 290p.

22. Penjit S. 2012. Prospect of Deoiled Jatropha curcas Seedcake as Fertilizer for Vegetables Crops - A Case Study. Journal of Agricultural Science. 4(3): 211-226

23. Reinhard KH, Tianasoa R. 2005. Le manuel Jatropha : un guide pour l'exploitation intégrée de la plante Jatropha à Madagascar. Allemagne. Green Island Association. 20 p.

24. Sall HM. 2007. Rapport annuel de projet biocarburant 2007-2012 : nouvelle orientation de la politique agricole au Sénégal. Ministre de Développement rural et de l'agriculture : 24p.

25. Singh G, Rathod TR. 2002. Plants growth biomass production and water dynamic in a shifting dume of Indian desert. Forest Ecology and management. 173 (3): 309-320.

26. Tchobsala, Dongock ND, Nyasiri J, Ibrahima A. 2016. Carbon storage of anthropoid's vegetation on the Ngaoundere escarpment (Adamawa. Cameroon). Journal of Advance in Biology 9 (2): 2347- 6893.

27. Tchuenteu TL, Megueni C, Njintang YN. 2013. A study of the variability for grain and oil yield and yield related traits of castor beans accessions in two savannah agro-ecological zones of Cameroon. International Journal of Biosciences. 3(8): p. 251-263. 